\title{
Protein S Deficiency Disease
}

National Cancer Institute

\section{Source}

National Cancer Institute. Protein S Deficiency Disease. NCI Thesaurus. Code C99026.

A rare thrombophilia disorder characterized by deficiency of protein S. It results in venous thromboembolism. 